\title{
Influence of boar contact on attainment of puberty in gilts after removal of the olfactory bulbs
}

\author{
R. N. Kirkwood, J. M. Forbes and P. E. Hughes \\ Department of Animal Physiology and Nutrition, University of Leeds, Leeds LS2 9JT, U.K.
}

\begin{abstract}
Summary. At 6-7 weeks of age the olfactory bulbs were removed from gilts which were then exposed to vasectomized boars for $30 \mathrm{~min} / \mathrm{day}$, starting on Day 160 . Mean \pm s.e.m. age at first oestrus was similar in these gilts $(230 \pm 15$ days $)$ to that in intact gilts not exposed to a boar $(234 \pm 8$ days $)$ but greater $(P<0.05)$ than for sham- and un-operated gilts exposed to a boar (204 \pm 3 and $208 \pm 9$ days, respectively). There were no differences in growth rate or ovulation rate at first oestrus. It is concluded that the main stimulus involved in the boar effect is olfactory in nature.
\end{abstract}

\section{Introduction}

The advancement of puberty in females by exposure to males has been demonstrated in many species, including the mouse (Vandenbergh, 1973), the prairie deer mouse (Teague \& Bradley, 1978), the rat (Vandenbergh, 1976) and the pig (Brooks \& Cole, 1970; Kirkwood \& Hughes, 1979). In rodent species the male stimulus has been demonstrated to be olfactory in nature (Vandenbergh, 1973). However, in the pig the nature of the boar stimulus has not been defined. The achievement of the boar effect involves various stimuli: olfactory and auditory cues (Signoret, 1970), the behaviour of the boar and a daily pen change. The change of pens is probably not a contributory factor (Kirkwood \& Hughes, 1980).

The present experiment was designed to assess the role of olfaction in the effect of the boar on puberty.

\section{Materials and Methods}

The 36 Large White $\times$ (Landrace $\times$ Large White) young female pigs (gilts) were from 9 litters, born within a 3-week period and weaned at 42 days of age. Gilts were randomly and equally allocated to groups: in Group 1 the olfactory bulbs were ablated and the gilts were exposed to the boar; in Group 2 the gilts were sham-operated and exposed to the boar; gilts in Group 3 were unoperated but exposed daily to the boar; the controls in Group 4 underwent no surgery or boar stimulation. There were insufficient gilts available to provide a control bulbectomy group (i.e. bulbectomy and no boar exposure).

The olfactory bulbs were removed from the gilts at 6-7 weeks of age using the technique of Signoret \& Mauleon (1962), as summarized by Meese \& Baldwin (1975a). Recovery was rapid and no adverse reactions were observed. For the sham operation, the full surgical procedure was performed, except that the offactory bulbs were left intact.

Gilts were housed in pens equipped with individual feeders and in groups of 4-6 depending on the date of starting the contact with the boar. In this way all gilts in any one pen were in 
the same treatment group and had first boar contact from the same date, thus minimizing the possibility of transferring stimuli of boar origin from treatment to pretreatment gilts. Gilts were fed commercial levels of a standard growing pig ration (17.6\% crude protein, $12.9 \mathrm{MJ}$ digestible energy $/ \mathrm{kg}$ ) to a maximum of $2.3 \mathrm{~kg}$ per day. Between puberty and the second oestrus this was increased to $2.7 \mathrm{~kg}$ per day to stimulate ovulation rate.

At an age of 160 days (Kirkwood \& Hughes, 1979), gilts were taken to 1 of 2 vasectomized boars for $30 \mathrm{~min}$ daily for stimulation and detection of oestrus. The attainment of puberty was taken as the first day of the first oestrous period, oestrus being detected by a standing heat reflex and acceptance of intromission by a vasectomized boar (Hughes \& Cole, 1976). The gilts went to the same boar throughout the trial, at the start of which the boars were 18 months of age. Gilts were slaughtered 5 days after the second oestrus. At this time the ovulation rate was assessed and the contents of the ethmoid fossa removed for histological examination to determine the thoroughness of the operative procedure.

The olfactory bulbs were fixed in situ in formol saline to facilitate removal. Fixation was continued after removal and standard histological procedures were used. The $10 \mu \mathrm{m}$ sections were stained with haematoxylin and eosin and studied for olfactory bulb structures, particularly glomeruli.

Overall differences in the data for puberty attainment were analysed by an analysis of variance. Between treatment differences were investigated using a least significant difference test.

\section{Results}

The results for puberty attainment are presented in Table 1: gilts in Group 2 did not differ significantly from those in Group 3 and there was no significant difference between Groups 1 and 4. However, the gilts in Groups 1 and 4 were significantly older at puberty than were those in Groups 2 and $3(P<0.05)$.

Table 1. The effects of the presence or absence of olfactory bulbs on the attainment of puberty (first oestrus) in gilts

\begin{tabular}{cccccc}
\hline Group (treatment) & $\begin{array}{c}\text { Age at puberty } \\
\text { (days) }\end{array}$ & $\begin{array}{c}\text { Time from boar } \\
\text { introduction to } \\
\text { puberty } \\
\text { (days) }\end{array}$ & Ovulation rate & $\begin{array}{c}\text { Growth rate to } \\
\text { days/puberty } \\
(\mathrm{kg} / \mathrm{day})\end{array}$ \\
\hline 1 & $\begin{array}{c}\text { (bulbectomy, boar } \\
\text { exposed) }\end{array}$ & $229.9 \pm 14.6^{\mathrm{ab}}$ & $69.9 \pm 14.6^{\mathrm{ef}}$ & $13.8 \pm 0.53$ & $0.51 \pm 0.004$ \\
2 & $204.0 \pm 2.5^{\mathrm{ac}}$ & $44.0 \pm 2.5^{\mathrm{eg}}$ & $14.7 \pm 0.78$ & $0.51 \pm 0.006$ \\
3 & $\begin{array}{c}\text { (sham-operation, } \\
\text { boar exposed) } \\
\text { (no operation, boar } \\
\text { exposed) }\end{array}$ & $207.6 \pm 8.5^{\mathrm{bd}}$ & $47.6 \pm 8.5^{\mathrm{fh}}$ & $13.5 \pm 0.65$ & $0.50 \pm 0.008$ \\
4 & $\begin{array}{c}\text { (controls, not boar } \\
\text { exposed) }\end{array}$ & $234.4 \pm 7.8^{\mathrm{cd}}$ & $74.4 \pm 7.8^{\mathrm{gh}}$ & $13.7 \pm 0.42$ & $0.50 \pm 0.008$ \\
\hline
\end{tabular}

Values are mean \pm s.e.m. for 9 gilts/group.

Values with a similar superscript letter are significantly different, $P<0.05$.

Examination of the contents of the ethmoid fossa did reveal some residual olfactory bulb material. The amount of tissue remaining was small (about 5\%) and its significance unknown. As noted by Murphy (1976), there was some infilling of the ethmoid fossa by forebrain tissue. During bulb removal from the head a total absence of nervous connections through the cribriform plate to the bulbs was noted.

Analysis of the data for ovulation rate, and growth rate from birth to puberty or 200 days of age (whichever occurred first) revealed no treatment- or pubertal age-dependent effects 
(see Table 1). There was no effect of bulbectomy on the ability to exhibit a standing heat reflex or on the length of the first oestrous cycle.

\section{Discussion}

The results presented indicate that olfactory bulb ablation prevents the boar effect on the attainment of puberty. However, there is some controversy in the literature as to the physiological consequences of removing the olfactory bulbs from pigs. Signoret \& Mauleon (1962) state that total olfactory bulb ablation of post-pubertal sows leads to a condition of anoestrus. only sows with some residual bulb material continuing to cycle normally. More recent evidence suggests that when the operation is performed on prepubertal gilts, it is followed by normal oestrous cycles and reproductive performances (Meese \& Baldwin, 1975a, b). These authors did not, however, note whether bulbectomy had any effect on the timing of first oestrus. In attempting an olfactory bulbectomy in any species care must be exercised to prevent interference with other neural structures, e.g. the supra optic region of the hypothalamus. In the pig pituitary/hypothalamic structures are not particularly vulnerable but other areas of the forebrain are. It is suggested that the anoestrous condition observed by Signoret \& Mauleon (1962) in sows with no trace of bulb material may be due to the accidental disruption of adjacent neural tissues. A further point not investigated in this or previous papers, but worthy of consideration, is the possibility of degenerative processes that may take place in other neural structures following olfactory bulb ablation. It seems reasonable to suggest that a near-total bulbectomy, as performed in the present experiment, will render a gilt anosmic and the interpretation of our results is based on this assumption. Ideally, a behavioural test for anosmia should be applied. The pig, however, is an extremely difficult animal to test in this context. The one possibility was a ' $T$ ' maze test employing the boar-seeking behaviour of oestrous gilts, but practical difficulties prevented the use of this test during the present experiment.

However, the results do indicate that olfactory cues are involved in the boar effect on the timing of puberty in the female pig. The role of specific pheromones produced by the boar has received some attention. It has been demonstrated that preputial fluid (Signoret, 1970), and the 16-unsaturated $\mathrm{C}_{19}$ steroids which are major testicular steroids in the pig, and accumulate in high concentration in the submaxillary glands (Gower, 1972; Booth, 1975) and saliva of boars (Booth \& Baldwin, 1980), have signalling pheromone properties (Reed, Melrose \& Patterson, 1974). However, no primer pheromone has yet been identified in the boar (Kinsey, Carlson, Proud \& Zimmerman, 1976; Kirkwood \& Hughes, 1980). It is feasible that the 16-androstene steroids present in boar saliva, particularly $3 a$-androstenol, may have a primer pheromone activity. Other primer pheromone(s), which may not be steroids, could also be present in the saliva. It is also possible that stress (Zimmerman, Bourn \& Donovan, 1976) such as may be involved in boar contact and olfactory cues act synergistically to bring about a primer pheromone effect. At the neural level, it has been demonstrated that 5 $\alpha$-androst-16-ene-3-one excites the mitral cells in the olfactory bulb of the pig (Macleod, Reinhardt \& Ellendorff, 1979), and that neural impulses arising from olfactory stimuli can be transmitted to areas of the brain involved in the control of reproductive functions, e.g. the amygdala and hypothalamus (Scott \& Pfaffmann, 1967; Macleod et al., 1979).

In conclusion, the results presented indicate a significant role for olfaction in the precocious induction of puberty in gilts kept in close proximity to a boar. The probable source of this stimulus is saliva released from the submaxillary salivary gland.

We thank the Wellcome Trust for supporting this study and $\mathrm{Mr} \mathrm{B}$. R. Warren and $\mathrm{Mr} \mathrm{T}$. D. Gibson for technical assistance. 


\section{References}

Booth, W.D. (1975) Changes with age in the occurrence of $\mathrm{C}_{19}$ steroids in the testis and submaxillary gland of the boar. J. Reprod. Fert. 42, 459-472.

Booth, W.D. \& Baldwin, B.A. (1980) Lack of effect on sexual behaviour or the development of testicular function after removal of olfactory bulbs in prepubertal boars. J. Reprod. Fert. 58, 173-182.

Brooks, P.H. \& Cole, D.J.A. (1970) Effect of the presence of a boar on attainment of puberty in gilts. J. Reprod. Fert. 23, 435-440.

Gower, D.B. (1972) 16-unsaturated $\mathrm{C}_{19}$ steroids. A review of their chemistry, biochemistry and possible physiological role. J. Steroid Biochem. 3, 45-103.

Hughes, P.E. \& Cole, D.J.A. (1976) Reproduction in the gilt. 2. Influence of gilt age at boar introduction on the attainment of puberty. Anim. Prod. 23, 89-94.

Kinsey, R.E., Carlson, R., Proud, C. \& Zimmerman, D.R. (1976) Influence of boar component stimuli on age at puberty in gilts. J. Anim. Sci. 42, 1362, Abstr.

Kirkwood, R.N. \& Hughes, P.E. (1979) The influence of age at first boar contact on puberty attainment in the gilt. Anim. Prod. 29, 231-238.

Kirkwood, R.N. \& Hughes, P.E. (1980) A note on the influence of 'boar effect' component stimuli on puberty attainment in the gilt. Anim. Prod. (In press).

Macleod, N.. Reinhardt, W. \& Ellendorff, F. (1979) Olfactory bulb neurons of the pig respond to an identified steroidal pheromone and testosterone. Brain Res. 164, 323-327.

Meese, G.B. \& Baldwin, B.A. (1975a) The effects of the ablation of the olfactory bulbs on aggressive behaviour in pigs. Appl. Anim. Ethol. 1, 251-262.

Meese, G.B. \& Baldwin, B.A. (1975b) Effects of olfactory bulb ablation on maternal behaviour of sows. Appl. Anim. Ethol. 1, 379-386.

Murphy, M.R. (1976) Olfactory impairment, olfactory bulb removal and mammalian reproduction. In Mammalian Olfaction, Reproductive Processes and Behavior, pp. 95-117. Ed. R. L. Doty. Academic Press, New York.

Reed, H.C.B., Melrose, D.R. \& Patterson, R.L.S. (1974) Androgen steroids as an aid to the detection of oestrus in pig artificial insemination. Br.vet.J. 130, 61-67.

Scott, J.W. \& Pfaffmann, C. (1967) Olfactory input to the hypothalamus, electro-physiological evidence. Science, N.Y. 158, 1592.

Signoret, J.P. (1970) Reproductive behaviour in pigs. J. Reprod. Fert., Suppl. 11, 105-117.

Signoret, J.P. \& Mauleon, P. (1962) Action de l'ablation des bulbes olfactifs sur les mecanismes de la reproduction chez la truie. Annls Biol. anim. Biochim. Biophys. 2, 167-174.

Teague, L. G. \& Bradley, E.L. (1978) The existence of a puberty accelerating pheromone in the urine of the male prairie deer mouse (Peromyscus maniculatus bairdii). Biol. Reprod. 19, 314-317.

Vandenbergh, J.G. (1973) Acceleration and inhibition of puberty in female mice by pheromones. J. Reprod. Fert. 19, 411-419.

Vandenbergh, J.G. (1976) Acceleration of sexual maturation in female rats by male stimulation. J. Reprod. Fert. 46, 451-453.

Zimmerman, D.R.. Bourn, P. \& Donovan. D. (1976) Effect of "transport phenomenon" stimuli and boar exposure on puberty in gilts. J. Anim. Sci. 42, 1362, Abstr. 